\title{
Primary colonic squamous cell carcinoma: a case report and review of the literature
}

\author{
D Linardoutsos ${ }^{1,2}$, M Frountzas $^{2}$, RM Feakins ${ }^{3}$, NH Patel ${ }^{1}$, V Simanskaite $^{3}$, H Patel $^{1}$ \\ ${ }^{1}$ Department of Colorectal Surgery, Barts Health NHS Trust, London UK \\ ${ }^{2}$ First Propaedeutic Department of Surgery, National and Kapodistrian \\ University of Athens, Hippocration General Hospital, Athens, Greece \\ ${ }^{3}$ Department of Histopathology, Barts Health NHS Trust, London UK \\ ABSTRACT
}

Colonic squamous cell carcinoma is extremely rare, with no clear pathogenesis. It usually presents as an emergency. We present the surgical management of a descending colon squamous cell carcinoma, together with a review of the available cases of colonic squamous cell carcinoma in the literature.

A 69-year-old woman presented with a palpable mass and abdominal pain. She underwent ultrasound and colonoscopy, which revealed a large obstructing mass at the descending colon, the biopsies of which were not diagnostic. Unfortunately, she was readmitted with bowel obstruction and underwent extended right hemicolectomy with en-bloc excision of attached small bowel and omentum because of local mass expansion. Histopathological analysis demonstrated squamous cell carcinoma with lymph node metastases. Palliative chemotherapy followed, owing to liver and peritoneal deposits.

Sixty-six cases of colonic squamous cell carcinoma have been reported in the literature. The most common location is the right colon. Most cases present at a late stage. Several theories for the pathogenesis of colonic squamous cell carcinoma have been reported; the most popular is the squamous transformation of a pluripotent stem cell.

\section{KEYWORDS}

Squamous cell carcinoma - Colorectal cancer

Accepted 10 May 2020

CORRESPONDENCE TO

Maximos Frountzas, E: froumax@hotmail.com

\section{Background}

Squamous cell carcinomas (SCC) of the gastrointestinal tract arise often from the oesophagus or anal canal. ${ }^{1}$ SCC of the colon and rectum are very rare and account for $0.1-0.25 / 1000$ colorectal carcinomas. ${ }^{2}$

The aetiology, pathogenesis and the optimal treatment strategies for colorectal SCC are not well established. We present a case of a SCC of the descending colon and a brief review of the literature regarding SCC of the colon.

\section{Case history}

A 69-year-old woman was referred to the outpatient colorectal clinic by her general practitioner with abdominal pain, weight loss, anaemia and a palpable mass in the left upper quadrant. An abdominal ultrasound suggested the presence of a soft tissue mass, probably originating from the transverse colon. A subsequent colonoscopy revealed a large obstructing mass in the descending colon, which was not passable. Colonoscopic biopsies were suspicious for a neoplastic lesion; however, the regimens were not diagnostic for either an adenocarcinoma or squamous cell carcinoma. Staging computed tomography (CT) of the chest, abdomen and pelvis showed no other distant metastatic disease at that time (Fig 1).

Unfortunately, the patient was subsequently admitted with symptoms of obstruction and underwent an emergency laparotomy, which revealed an obstructing descending colon tumour with attached loop of distal jejunum, omentum and abdominal wall. An extended right hemicolectomy with en-bloc excision of attached small bowel and omentum and anterior abdominal wall was performed. The patient had an uneventful postoperative recovery.

Histological examination revealed a moderately differentiated SCC of the descending colon with no areas of adenocarcinoma (Fig 2). However, metastases were present in 3 of 38 lymph nodes presenting the features of adenocarcinoma. The adjacent small bowel loop that was excised and the attached abdominal wall were also invaded by SCC. Extramural venous invasion was seen. The resection margins were not involved; the lesion was staged as pT4 pN1. No adjacent adenoma was identified. 
The possibility that this mass represented a metastasis from another primary site required investigation, according to the advisory of the multidisciplinary team meeting. A gastroscopy showed no upper gastrointestinal abnormality and CT of the chest, abdomen and pelvis was otherwise clear. In addition, serum tumour markers, such as carcinoembryonic antigen, were not elevated. Another primary site was therefore excluded, and the most possible scenario according to the histopathological report was a primary adenosquamous carcinoma of the bowel, but with occult adenocarcinoma component of metastases in the adjacent lymph nodes with adenocarcinoma characteristics.

The patient developed progressive disease. Positron emission tomography showed avid peritoneal and liver deposits. Consequently, she was subsequently offered palliative chemotherapy.

\section{Discussion}

Primary SCC of the colon is a very rare entity, accounting for $0.1-0.25 \%$ of all colorectal malignancies. ${ }^{2-4}$ The first case of colonic SCC reported in the literature was in 1919 , by Schmidtmann. ${ }^{5}$ The first rectal SCC was reported in 1933 by Raiford. ${ }^{6}$ Since then, approximately 150 cases of colorectal SCC have been reported, with the majority arising from the rectum. The second most frequent site of colorectal SCC is the right colon (Table 1). There have been only 64 cases of primary colonic SCC reported previously in English literature. ${ }^{6-10}$ The average age at presentation is the fifth decade, with no clear sex bias. ${ }^{8-11}$ The majority of colonic SCC present in advanced stages.

Several hypotheses have been postulated to explain the pathophysiology of the disease. The first hypothesis suggests the association of SCC with a chronic inflammatory process involving the colon. Malignancies arising from colocutaneous fistulas may represent an example of that theory. In addition, there are reports of colonic SCC in patients with ulcerative colitis, schistosomiasis and infection by Entamoeba histolytica and human papilloma virus (HPV). ${ }^{13-17}$ However, the association between colorectal SCC and HPV infection is not confirmed. ${ }^{18}$ Another hypothesis suggests the differentiation of multipotent stem cells to squamous cell dysplasia and subsequently carcinoma. ${ }^{19}$ Others refer to the possibility of activation of uncommitted cells towards squamous cell differentiation, ending with malignant squamous transformation. ${ }^{20}$ Finally, another pathogenetic hypothesis is squamous differentiation in pre-existing adenomas or adenocarcinomas of the colon, as there are multiple studies, which show synchronous or metachronous adenocarcinomas or adenosquamous tumours in pre-existing irritable bowel disease. ${ }^{14,21-26}$

Our patient did not seem to have any predisposing factor such as HPV or Schistosoma infection, or an underlying colocutaneous fistula. It may have arisen as a result of biphasic differentiation of a multipotent stem cell. This might have resulted in an adenosquamous carcinoma initially, leading to the dominance of squamous cell component. This may explain the presence of adenocarcinoma cells within the retrieved lymph nodes.

The symptoms of patients with colonic SCC are similar to those who have colonic adenocarcinoma. The duration of the symptoms often ranges from several weeks to months. ${ }^{12,26,27}$ A change in bowel habit, rectal bleeding, abdominal pain and weight loss are also common. Additionally, because of the increased likelihood of advanced stage at presentation, anaemia and palpable masses could be manifestations of the disease.

During colonoscopy, it is essential that multiple biopsies are taken from the suspected lesion. The endoscopic appearance of SCC varies from a polyp to a malignant-looking lesion. Care should be taken to explore the entire colon to exclude other synchronous lesions, which are not rare in this setting. ${ }^{23-25}$ Modern endoscopic techniques such as narrow band imaging have been useful in the detection of subtler colonic lesions, highlighting the colonic mucosa and underlying capillary networks. ${ }^{28}$ On the other hand, the diagnosis of SCC could be established

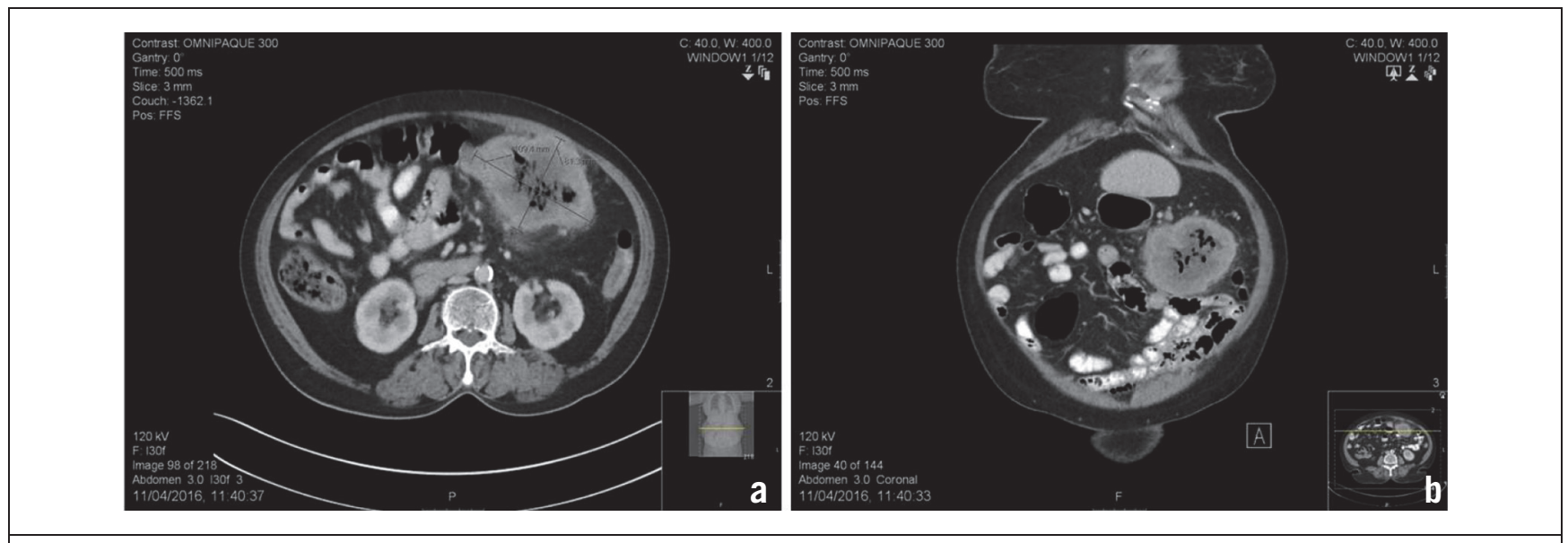

Figure 1 Computed tomography showing the primary tumour at the descending colon 
only after histological examination. Immunohistochemistry may help with the differential diagnosis in difficult cases. CAM 5.2, AE1/AE3 and 34B12 are useful stains for characterising lesions as SCC rather than another neoplasm. ${ }^{21,29-31}$

Certain diagnostic criteria have been proposed to establish the diagnosis of SCC of the colon and rectum. Williams et al established diagnostic criteria for SCC of the rectum. ${ }^{14}$ According to these criteria, a metastasis from other squamous malignancies of the body must be excluded first. In addition, the presence of a concurrent fistula tract involved with the lesion must be excluded, because the SCC may originate from the squamous epithelium within the tract. Especially for rectal tumours, proximal extension of an anal squamous lesion must also be excluded. Finally, histological confirmation of the squamous content of the lesion must be obtained without glandular differentiation. ${ }^{14,32}$ In our case, it seems that the colonic lesion consists of squamous malignant cells only, not suggesting a mixed colonic adenosquamous lesion. However, we do not have a clear explanation for the deposits of adenocarcinoma in three lymph nodes. No other lesion was found suggesting colonic adenocarcinoma, or any other evidence of adenoma type lesion on CT.

The rarity of these tumours in the colon precludes the establishment of guidelines for the treatment of colonic SCC. Prognosis is also difficult to be assessed as most of the reported cases have presented in the latter stages of disease. Thus, based on historical data, the overall five-year survival is of the order of $35 \%$. Furthermore, these patients were often treated by surgery alone. The role of modern oncology therapies may further improve outcomes, as neoadjuvant chemotherapy and radiotherapy have developed a principle role recently. ${ }^{34,35}$ This may be reflected in the outcome of more recent cases which seem to have better overall survival. ${ }^{12,15,33}$ Negative margins and complete excision are crucial. Frizelle et al, evaluating 52 patients with squamous and adenosquamous cell carcinoma of the colon, reported similar prognosis for early SCC, stages I-II, comparable to colonic adenocarcinoma. However, overall and especially in later stages, the prognosis of colonic SCC is poor. Mixed adenosquamous carcinomas and poor differentiation seem to be associated with a poorer prognosis. ${ }^{24}$

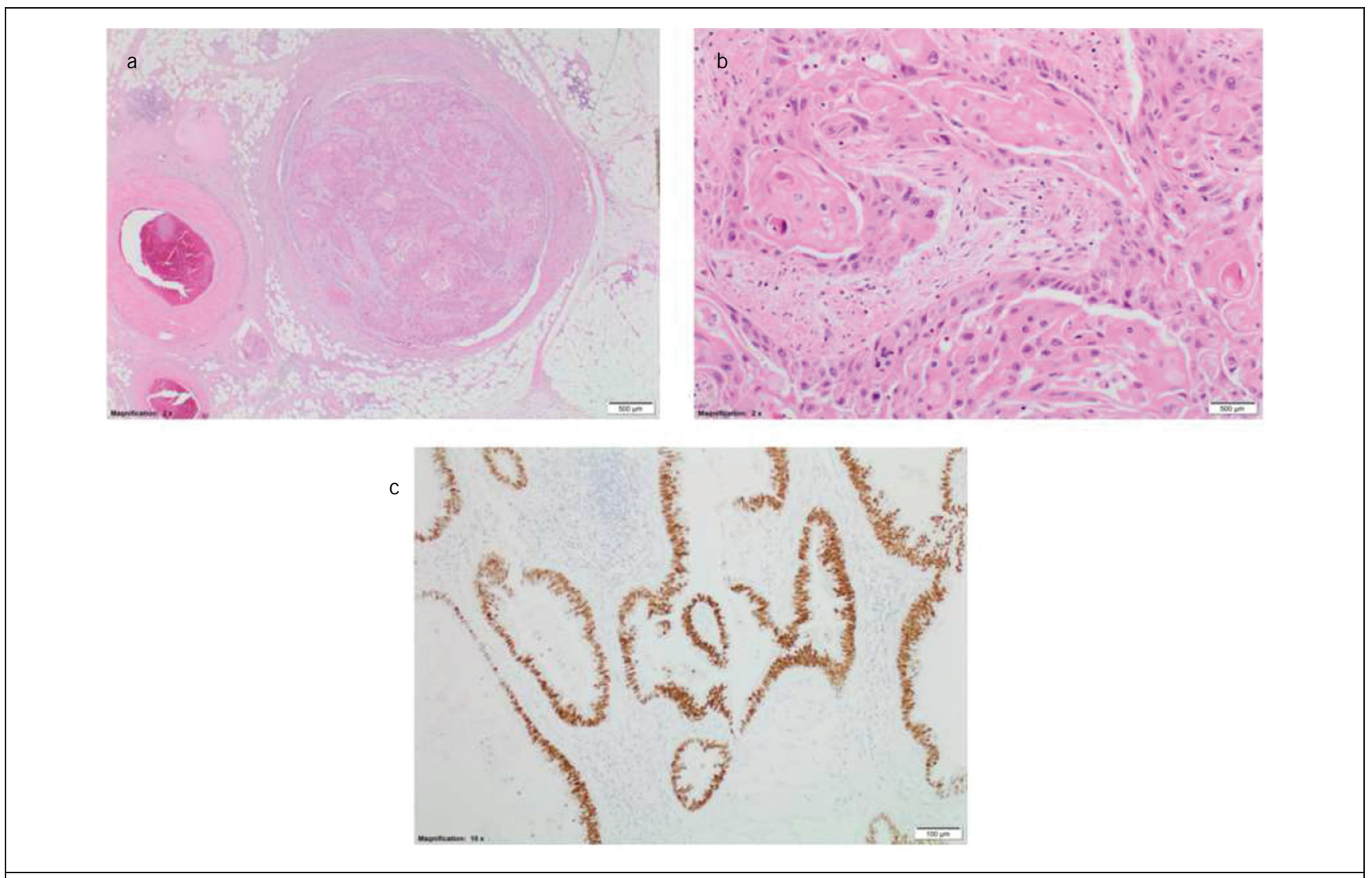

Figure 2 Histological examination with haematoxylin and eosin stain: a) showing squamous extramural venous invasion; b) the squamous-cell carcinoma. c) Histologic examination with Masson stainshowing lymph node invasion. 
Table 1 Cases of squamous cell carcinoma of the colon

\begin{tabular}{|c|c|c|c|c|c|}
\hline Case & $\begin{array}{l}\text { Age } \\
\text { (years) }\end{array}$ & Sex & Location & Treatment & Clinical outcome \\
\hline $\begin{array}{l}\text { Schmidtmann } \\
(1919)^{5}\end{array}$ & 65 & male & cecum & $\mathrm{n} / \mathrm{a}$ & $\begin{array}{l}\text { died of disease } \\
\text { at } 1 \text { month }\end{array}$ \\
\hline $\begin{array}{l}\text { Hicks and } \\
\text { Cowling }(1955)^{36}\end{array}$ & 90 & female & ascending colon & $\mathrm{n} / \mathrm{a}$ & $\begin{array}{l}\text { died of disease } \\
\text { at } 1 \text { month }\end{array}$ \\
\hline $\begin{array}{l}\text { Larizadeh and } \\
\text { Powell }(1965)^{37}\end{array}$ & 44 & female & hepatic flexure & right hemicolectomy & alive at 8 months \\
\hline Wood $(1967)^{38}$ & 58 & male & cecum & right hemicolectomy & $\mathrm{n} / \mathrm{a}$ \\
\hline Minkowitz $(1967)^{23}$ & 49 & female & lower sigmoid & proctocolectomy & dead at 5 months \\
\hline Gaston $(1967)^{39}$ & 67 & male & cecum & $\mathrm{n} / \mathrm{a}$ & $\mathrm{n} / \mathrm{a}$ \\
\hline $\begin{array}{l}\text { Pemberton and } \\
\text { Lendrum }(1968)^{40}\end{array}$ & 65 & female & ascending colon & right hemicolectomy & alive at 2 years \\
\hline Birnbaum $(1970)^{41}$ & 82 & male & ascending colon & right hemicolectomy & $\mathrm{n} / \mathrm{a}$ \\
\hline \multirow[t]{8}{*}{ Comer et al $(1971)^{15}$} & $\mathrm{n} / \mathrm{a}$ & $\mathrm{n} / \mathrm{a}$ & rectum at $8 \mathrm{~cm}$ & $\mathrm{n} / \mathrm{a}$ & $\mathrm{n} / \mathrm{a}$ \\
\hline & $\mathrm{n} / \mathrm{a}$ & $\mathrm{n} / \mathrm{a}$ & transverse colon & $\mathrm{n} / \mathrm{a}$ & $\mathrm{n} / \mathrm{a}$ \\
\hline & $\mathrm{n} / \mathrm{a}$ & $\mathrm{n} / \mathrm{a}$ & descending colon & $\mathrm{n} / \mathrm{a}$ & $\mathrm{n} / \mathrm{a}$ \\
\hline & $\mathrm{n} / \mathrm{a}$ & $\mathrm{n} / \mathrm{a}$ & upper rectum & $\mathrm{n} / \mathrm{a}$ & $\mathrm{n} / \mathrm{a}$ \\
\hline & $\mathrm{n} / \mathrm{a}$ & $\mathrm{n} / \mathrm{a}$ & ascending colon & $\mathrm{n} / \mathrm{a}$ & $\mathrm{n} / \mathrm{a}$ \\
\hline & $\mathrm{n} / \mathrm{a}$ & $\mathrm{n} / \mathrm{a}$ & hepatic flexure & $\mathrm{n} / \mathrm{a}$ & $\mathrm{n} / \mathrm{a}$ \\
\hline & $\mathrm{n} / \mathrm{a}$ & $\mathrm{n} / \mathrm{a}$ & sigmoid & $\mathrm{n} / \mathrm{a}$ & $\mathrm{n} / \mathrm{a}$ \\
\hline & $\mathrm{n} / \mathrm{a}$ & $\mathrm{n} / \mathrm{a}$ & sigmoid & $\mathrm{n} / \mathrm{a}$ & $\mathrm{n} / \mathrm{a}$ \\
\hline $\begin{array}{l}\text { Lewis et al } \\
(1971)^{42}\end{array}$ & 61 & male & cecum & right hemicolectomy & $\begin{array}{l}\text { dead } 10 \text { days } \\
\text { postoperatively }\end{array}$ \\
\hline Balfour $(1972)^{43}$ & 63 & male & sigmoid & sigmoidectomy & alive at 18 months \\
\hline $\begin{array}{l}\text { Horne and McCulloch } \\
\text { et al (1978) }\end{array}$ & 53 & male & cecum & right hemicolectomy & dead at 11 months \\
\hline Crissman $(1978)^{45}$ & 72 & male & transverse colon & colectomy & $\begin{array}{l}\text { dead } 3 \text { days } \\
\text { postoperatively }\end{array}$ \\
\hline $\begin{array}{l}\text { Burgess et al } \\
(1979)^{46}\end{array}$ & 43 & male & hepatic flexure & right hemicolectomy & dead at 1 year \\
\hline Khan et al $(1979)^{47}$ & 64 & male & ascending colon & $\mathrm{n} / \mathrm{a}$ & $\mathrm{n} / \mathrm{a}$ \\
\hline $\begin{array}{l}\text { Hickey and Corson } \\
(1981)^{48}\end{array}$ & 48 & female & transverse colon & left hemicolectomy & alive at 21 months \\
\hline Petrelli et al $(1981)^{49}$ & 73 & male & sigmoid & palliative colostomy & $\begin{array}{l}\text { dead } 9 \text { days } \\
\text { postoperatively }\end{array}$ \\
\hline $\begin{array}{l}\text { Pitella and Torres } \\
(1982)^{10}\end{array}$ & 33 & male & ascending colon & colonic bypass & $\begin{array}{l}\text { dead } 10 \text { days } \\
\text { postoperatively }\end{array}$ \\
\hline \multirow[t]{2}{*}{ Hey and Brandt $(1982)^{50}$} & $\mathrm{n} / \mathrm{a}$ & $\mathrm{n} / \mathrm{a}$ & colon & $\mathrm{n} / \mathrm{a}$ & $\mathrm{n} / \mathrm{a}$ \\
\hline & $\mathrm{n} / \mathrm{a}$ & $\mathrm{n} / \mathrm{a}$ & colon & right hemicolectomy & alive 2 months \\
\hline Lyttle $(1983)^{51}$ & 65 & female & ascending colon & right hemicolectomy & alive at 2 months \\
\hline $\begin{array}{l}\text { Vezeridis et al } \\
(1983)^{52}\end{array}$ & 56 & male & rectum at $10 \mathrm{~cm}$ & $\begin{array}{l}\text { abdominoperineal } \\
\text { resection }\end{array}$ & intraoperative death \\
\hline Gould et al $(1983)^{53}$ & 56 & male & splenic flexure & ileocolic bypass & died after 3 months \\
\hline $\begin{array}{l}\text { Francioni et al } \\
(1983)^{54}\end{array}$ & 61 & male & transverse colon & $\mathrm{n} / \mathrm{a}$ & $\mathrm{n} / \mathrm{a}$ \\
\hline Forouhar $(1984)^{55}$ & $\mathrm{n} / \mathrm{a}$ & $\mathrm{n} / \mathrm{a}$ & colon & right hemicolectomy & $\mathrm{n} / \mathrm{a}$ \\
\hline
\end{tabular}




\begin{tabular}{|c|c|c|c|c|c|}
\hline $\begin{array}{l}\text { Michelassi et al } \\
(1988)^{8}\end{array}$ & $\mathrm{n} / \mathrm{a}$ & $\mathrm{n} / \mathrm{a}$ & cecum & right hemicolectomy & survival 1 month \\
\hline Balsano $(1985)^{56}$ & 65 & male & colon & right hemicolectomy & $\mathrm{n} / \mathrm{a}$ \\
\hline Michelassi $(1988)^{16}$ & $\mathrm{n} / \mathrm{a}$ & $\mathrm{n} / \mathrm{a}$ & ascending colon & right hemicolectomy & survival 18 month \\
\hline Chulia et al (1986) ${ }^{9}$ & 65 & male & cecum & $\mathrm{n} / \mathrm{a}$ & $\mathrm{n} / \mathrm{a}$ \\
\hline \multirow[t]{3}{*}{ Navarro $(1986)^{57}$} & 58 & male & ascending colon & $\mathrm{n} / \mathrm{a}$ & $\mathrm{n} / \mathrm{a}$ \\
\hline & $\mathrm{n} / \mathrm{a}$ & $\mathrm{n} / \mathrm{a}$ & hepatic flexure & $\mathrm{n} / \mathrm{a}$ & $\mathrm{n} / \mathrm{a}$ \\
\hline & $\mathrm{n} / \mathrm{a}$ & $\mathrm{n} / \mathrm{a}$ & colon & $\mathrm{n} / \mathrm{a}$ & $\mathrm{n} / \mathrm{a}$ \\
\hline Shao et al $(1987)^{58}$ & $\mathrm{n} / \mathrm{a}$ & $\mathrm{n} / \mathrm{a}$ & colon & right hemicolectomy & $\mathrm{n} / \mathrm{a}$ \\
\hline Lundquest et al (1988) ${ }^{59}$ & $\mathrm{n} / \mathrm{a}$ & $\mathrm{n} / \mathrm{a}$ & colon & $\mathrm{n} / \mathrm{a}$ & $\mathrm{n} / \mathrm{a}$ \\
\hline McMahon $(1991)^{60}$ & 63 & female & ascending colon & $\mathrm{n} / \mathrm{a}$ & $\mathrm{n} / \mathrm{a}$ \\
\hline Wyatt et al (1991) ${ }^{61}$ & 71 & male & right colon & right hemicolectomy & alive at 1 year \\
\hline $\begin{array}{l}\text { Betancourt et al } \\
(1992)^{62}\end{array}$ & $\mathrm{n} / \mathrm{a}$ & female & transverse colon & $\mathrm{n} / \mathrm{a}$ & alive 1 year \\
\hline Vingnale et al (1993) ${ }^{63}$ & 69 & male & sigmoid colon & surgery & alive at 8 months \\
\hline Yoshida et al (1994) ${ }^{11}$ & 51 & male & cecum & left hemicolectomy & $\begin{array}{l}\text { died } 39 \text { days from } \\
\text { diagnosis }\end{array}$ \\
\hline Vraux et al (1994) & $\mathrm{n} / \mathrm{a}$ & $\mathrm{n} / \mathrm{a}$ & hepatic flexure & chemotherapy & died after 5 years \\
\hline Alekseev et al (1994) ${ }^{65}$ & 69 & male & sigmoid colon & $\mathrm{n} / \mathrm{a}$ & 5 years' survival \\
\hline Petrelli et al $(1996)^{25}$ & 62 & male & rectum & $\begin{array}{l}\text { abdominoperineal } \\
\text { resection }\end{array}$ & $\mathrm{n} / \mathrm{a}$ \\
\hline \multirow[t]{2}{*}{ Juturi et al (1999) } & 61 & female & hepatic flexure & $\begin{array}{l}\text { right hemicolectomy + } \\
\text { chemotherapy }\end{array}$ & $\begin{array}{l}\text { alive with no evidence } \\
\text { of disease } 18 \text { years } \\
\text { after diagnosis }\end{array}$ \\
\hline & 67 & male & ascending colon & $\begin{array}{l}\text { left hemicolectomy and } \\
\text { chemotherapy }\end{array}$ & $\begin{array}{l}\text { dead of disease at } \\
15 \text { months }\end{array}$ \\
\hline $\begin{array}{l}\text { Goodfellow et al } \\
(1999)^{66}\end{array}$ & 66 & male & hepatic flexure & right hemicolectomy & $\mathrm{n} / \mathrm{a}$ \\
\hline Copur et al $(2001)^{35}$ & 54 & male & rectosigmoid & $\begin{array}{l}\text { abdominoperineal } \\
\text { resection }+ \\
\text { chemotherapy }\end{array}$ & $\mathrm{n} / \mathrm{a}$ \\
\hline Miyamoto et al (2007) & 89 & male & descending colon & descending colonectomy & $\begin{array}{l}\text { dead } 3 \text { months after } \\
\text { surgery }\end{array}$ \\
\hline \multirow[t]{2}{*}{ Fahim et al (2006) ${ }^{67}$} & 35 & male & rectum & $\begin{array}{l}\text { abdominoperineal } \\
\text { resection }\end{array}$ & $\begin{array}{l}\text { died } 11 \text { months } \\
\text { post-surgery }\end{array}$ \\
\hline & 68 & female & rectosigmoid colon & palliative treatment & $\begin{array}{l}\text { died } 3 \text { months after } \\
\text { diagnosis }\end{array}$ \\
\hline Hashimoto $(2013)^{68}$ & 80 & female & sigmoid & sigmoidectomy & survival 15 months \\
\hline Rajan et al (2014) & 77 & male & splenic flexure & $\begin{array}{l}\text { extended right } \\
\text { hemicolectomy }\end{array}$ & $\begin{array}{l}\text { died } 1 \text { month } \\
\text { post-surgery }\end{array}$ \\
\hline Lannaz et al (2015) & 55 & male & cecum & $\begin{array}{l}\text { right hemicolectomy + } \\
\text { chemotherapy }\end{array}$ & $\begin{array}{l}\text { alive } 12 \text { months } \\
\text { post-surgery }\end{array}$ \\
\hline Al-Shelfa et al $(2015)^{7}$ & 34 & male & transverse colon & surgical excision & n/a, lost to follow-up \\
\hline Ito et al $(2016)^{69}$ & 75 & female & transverse colon & $\begin{array}{l}\text { laparoscopic right } \\
\text { hemicolectomy }\end{array}$ & $\begin{array}{l}\text { alive, disease free at } \\
18 \text { months post-surgery }\end{array}$ \\
\hline Ngo et al $(2014)^{70}$ & 53 & male & sigmoid colon & $\begin{array}{l}\text { extended right } \\
\text { hemicolectomy } \\
+ \text { chemotherapy }\end{array}$ & alive \\
\hline Samo et al $(2015)^{71}$ & 81 & female & sigmoid colon & chemotherapy & survival 5 months \\
\hline Ahmad et al $(2015)^{72}$ & 46 & female & cecum & $\begin{array}{l}\text { Proctocolectomy + } \\
\text { mesorectal excision } \\
\text { and intersphincteric } \\
\text { dissection }\end{array}$ & $\begin{array}{l}\text { alive at 12-month } \\
\text { follow-up }\end{array}$ \\
\hline
\end{tabular}




\begin{tabular}{|c|c|c|c|c|c|}
\hline Mohamed $(2017)^{73}$ & 54 & male & splenic flexure & colectomy & $\begin{array}{l}\text { alive at 12-month } \\
\text { follow-up }\end{array}$ \\
\hline \multirow[t]{2}{*}{$\begin{array}{l}\text { Abdelqader et al } \\
(2017)^{74}\end{array}$} & 27 & female & ascending colon & right hemicolectomy & $\begin{array}{l}\text { alive } 2.5 \text { years } \\
\text { post-surgery }\end{array}$ \\
\hline & 44 & male & ascending colon & $\begin{array}{l}\text { right hemicolectomy + } \\
\text { chemotherapy + } \\
\text { radiotherapy }\end{array}$ & $\begin{array}{l}\text { died } 6 \text { months } \\
\text { after diagnosis }\end{array}$ \\
\hline Our case & 69 & female & transverse colon & $\begin{array}{l}\text { right hemicolectomy + } \\
\text { chemotherapy }\end{array}$ & $\mathrm{n} / \mathrm{a}$ \\
\hline
\end{tabular}

\section{Conclusion}

Colorectal SCC is a very rare clinical entity, with a poorly understood pathogenesis. Clinicians should be aware of the possibility of colorectal SCC, particularly in cases presenting at a late stage. The presence of SCC elsewhere in the body must be excluded before a diagnosis of primary colonic SCC is made. A multidisciplinary approach to management is key to improving outcomes. Owing to the rarity of the reported cases, we propose the establishment of an international registry of all colorectal SCC, although we are not sure what the cost-benefit ratio might be.

\section{References}

1. Novak ER, Wooddruff JD, Gynecologic and Obstetric Pathology. 5th ed. Philadelphia: WB Saunders; 1962.

2. Gelas $T$, Peyrat $P$, Francois $Y$ et al: Primary squamous cell carcinoma of the rectum. Dis Colon Rectum 2002; 45: 1535-1540.

3. Morson BC, Sobin LH. Histological Typing of Intestinal Tumours. WHO Technical Report 15. Geneva: World Health Organization; 1976.

4. Leung KK, Heitzman J, Madan A. Squamous cell carcinoma of the rectum 21 years after radiotherapy for cervical carcinoma. Saudi J Gastroenterol 2009; 15: 196-198.

5. Schmidtmann M. Zur kenntnis seltener krebsformen. Virch Arch Pathol 1919; 226: 100-118.

6. Lannaz S, Elomrani F, Ouziane I et al. Squamous cell carcinoma of the colon: a case report and literature review. Austin J Clin Med 2015; 2: 1023.

7. Al-Shelfa W, Al-Sadik M, Al-Nakoury E et al. Primary squamous cell carcinoma of the transverse colon: report of a case. Saudi Surg J 2015; 3: 82-84.

8. Michelassi F, Mishlove LA, Stipa F, Block GE. Squamous cell carcinoma of the colon: experience at the University of Chicago, review of the literature, report of two cases. Dis Colon Rectum 1988; 31: 228-235.

9. Chulia F, Camps C, Rodriguez A et al. Epidermoid carcinoma of the colon: description of a lesion located in the hepatic flexure. Dis Colon Rectum 1986; 29: 665-667.

10. Pitella JE, Torres AV. Primary squamous-cell carcinoma of the cecum and ascending colon: report of a case and review of the literature. Dis Colon Rectum 1982; 25: 483-487.

11. Yoshida J, Tohma H, Nagata $T$ et al. Squamous cell carcinoma of the splenic flexure of the colon: report of a case. Surg Today 1994; 24: 75-79.

12. Miyamoto $\mathrm{H}$, Nishioka $\mathrm{M}$, Kurita $\mathrm{N}$ et al. Squamous cell carcinoma of the descending colon: report of a case and literature review. Case Rep Gastroenterol 2007; 1: 77-83.

13. Wiener MF, Polayes SH, Yidi R. Squamous carcinoma with schistostomiasis of the colon. Am J Gastroenterol 1962; 37: 48-54.

14. Williams GT, Blackshaw AJ, Morson BC. Squamous carcinoma of the colon and its genesis. J Pathol 1979; 129: 139-147.

15. Comer TP, Beahrs OH, Dockerty MB. Primary squamous cell carcinoma and adenocarcinoma of the colon. Cancer 1971; 28: 1111-1117.

16. Michelassi F, Montag AG, Block GE. Adenosquamous-cell carcinoma in ulcerative colitis: report of a case. Dis Colon Rectum 1988; 31: 323-326.
17. Ouban A, Nawab RA, Coppola D. Diagnostic and pathogenetic implications of colorectal carcinomas with multidirectional differentiation: a report of 4 cases. Clin Colorectal Cancer 2002; 1: 243-248.

18. Audeau A, Han HW, Johnston MJ et al. Does human papiloma virus have a role in squamous cell carcinoma of the colon and upper rectum? Eur J Surg Oncol 2002; 28: 657-660.

19. Palvio DH, Sorensen FB, Mogensen KM. Stem cell carcinoma of the colon and rectum: report of two cases and review of the literature. Dis Colon Rectum 1985; 28: 440-445.

20. Lam AK, Ho YH. Primary squamous cell carcinoma of the rectum in a patient on immunosuppressive therapy. Pathology 2006; 38: 74-76.

21. Dyson T, Draganov PV. Squamous cell cancer of the rectum. World $J$ Gastroenterol 2009; 15: 4380-4386.

22. Kulaylat MN, Doerr R, Butler B et al. Squamous cell carcinoma complicating idiopathic inflammatory bowel disease. J Surg Oncol 1995; 59: 48-55.

23. Minkowitz S. Primary squamous cell carcinoma of the rectosigmoid portion of the colon. Arch Pathol 1967; 84: 77-80.

24. Frizelle FA, Hobday KS, Batts KP et al. Adenosquamous and squamous carcinoma of the colon and upper rectum: a clinical and histopathologic study. Dis Colon Rectum 2001; 44: 341-346.

25. Petrelli NJ, Valle AA, Weber TK et al. Adenosquamous carcinoma of the colon and rectum. Dis Colon Rectum 1996; 39: 1265-1268.

26. Vezeridis MP, Herrera LO, Lopez GE et al. Squamous cell carcinoma of the colon and rectum. Dis Colon Rectum 1983; 26: 188-191.

27. Aevlovschi C, Comandaeu M, Aerban D. Particularities of diagnosis and treatment in synchronous colorectal cancers. Chirourgia 2013; 108: 43-45.

28. Fu K, Tsujinaka Y, Hamahata $Y$ et al. Squamous metaplasia of the rectum associated with ulcerative colitis diagnosed using narrow band imaging. Endoscopy 2008; 40(Suppl 2): E45-E46.

29. Anagnostopoulos G, Sakorafas GH, Kostopoulos $P$ et al. Squamous cell carcinoma of the rectum: a case report and review of the literature. Eur $J$ Cancer Care (Engl) 2005; 14: 70-74.

30. Nahas CS, Shia J, Joseph R et al. Squamous-cell carcinoma of the rectum: a rare but curable tumor. Dis Colon Rectum 2007; 50: 1393-1400.

31. Yaziji H, Broghamer WL. Primary small cell undifferentiated carcinoma of the rectum associated with ulcerative colitis. South Med J 1996; 89: 921-924.

32. Caroll D, Rajesh PB. Colonic metastases from primary squamous cell carcinoma of the lung. Eur J Cardiothorac Surg 2001; 19: 719-720.

33. Rajan R, Baqar A, Menon T. An interesting case of primary squamous cell carcinoma of the colon with synchronous metastatic adenocarcinoma. Clin Case Rep 2014; 2: 323-325.

34. Juturi JV, Francis B, Koontz PW et al. Squamous-cell carcinoma of the colon responsive to combination chemotherapy. Dis Colon Rectum 1999; 42 102-109.

35. Copur S, Ledakis $P$, Novinski $D$ et al. Squamous cell carcinoma of the colon with an elevated serum squamous cell carcinoma antigen responding to combination chemotherapy. Clin Colorectal Cancer 2001; 1: 55-58.

36. Hicks JD, Cowling DC. Squamous-cell carcinoma of the ascending colon. J Pathol Bacteriol 1955; 70: 205-212.

37. Larizadeh R, Powell DE. Neoplastic change in a duplicated colon. Br J Surg 1965; 52: 666-668.

38. Wood DH. Squamous cell carcinoma of the large intestine. Atlas of Tumor Pathology 1967; Sec 6, facs 22: 194.

39. Gaston EA. Squamous-cell carcinoma of the colon and rectum: report of a case. Dis Colon Rectum 1967; 10: 435-442. 
40. Pemberton M, Lendrum J. Squamous-cell carcinoma of the caecum following ovarian adenocarcinoma. Br J Surg 1968; 55: 273-276.

41. Birnbaum W. Squamous cell carcinoma and adenoacanthoma of the colon. JAMA 1970; 1: 1511-1513.

42. Lewis PL, Harrer WV, Sencindiver PV. Primary squamous-cell carcinoma of the cecum: report of a case. Dis Colon Rectum 1971; 14: 213-217.

43. Balfour TW. Does squamous carcinoma of the colon exist? Br J Surg 1972; 59: 410-412.

44. Horne BD, McCulloch CF. Squamous cell carcinoma of the cecum. Cancer 1978; 42: 1879-1882.

45. Crissman JD. Adenosquamous and squamous cell carcinoma of the colon. Am J Surg Pathol 1978; 2: 47-54.

46. Burgess PA, Lupton EW, Talbot IC. Squamous-cell carcinoma of the proximal colon: report of a case and review of the literature. Dis Colon Rectum 1979; 22: 241-244.

47. Kahn AQ, Griffin JW, Tedesco FJ. Squamous cell carcinoma of the ascending colon. Am J Gastroenterol 1979; 72: 565-567.

48. Hickey WF, Corson JM. Squamous cell carcinoma arising in a duplication of the colon: case report and literature review of squamous cell carcinoma of the colon and of malignancy complicating colonic duplication. Cancer 1981; 47: 602-609.

49. Petrelli M, Tetangco E, Reid JD. Carcinoma of the colon with undifferentiated, carcinoid, and squamous cell features. Am J Clin Pathol 1981; 75: 581-584.

50. Hey A, Brandt G. [A Pure Squamous Cell Carcinoma of the Large Intestine. Report of 3 Personal Observations and a Literature Review]. Pathologe 1982; 3: 359-364.

51. Lyttle JA. Primary squamous carcinoma of the proximal large bowel: report of a case and review of the literature. Dis Colon Rectum 1983; 26: 279-282.

52. Vezeridis MP, Herrera LO, Lopez GE et al. Squamous-cell carcinoma of the colon and rectum. Dis Colon Rectum 1983; 26: 188-191.

53. Gould L, Shah JM, Khedekar RR, Burns WA. Squamous cell carcinoma of the splenic flexure of the colon. Dig Dis Sci 1983; 28: 918-922.

54. Francioni G, Canuti S, Cardelli A, Montesi M. [Epidermoid carcinoma of the colon: clinical case of double recto-sigmoid basalioma]. Minerva Dietol Gastroenterol 1983; 29: 33-38.

55. Forouhar F. Neoplastic colonic polyp with extensive squamous metaplasia: case report. Tumori 1984; 70: 99-103.

56. Balsano NA. Squamous cell carcinoma of the cecum. Arch Surg 1985; 120: 1176-1177.

57. Navarro Fos S, Ferrández Izquierdo A, Vera Sempere F et al. Carcinomas of the colon with squamous differentiation: a histological and immunohistochemical study of 3 cases. Rev Esp Enferm Apar Dig 1986; 70: 389-393.
58. Shao YF, Pan GL, Zhou CN, Yu HT. [Squamous cell carcinoma of the ascending colon: a case report and review of literature]. Zhonghua Zhong Liu Za Zhi 1987; 9: 315-316.

59. Lundquest DE, Marcus JN, Thorson AG, Massop D. Primary squamous cell carcinoma of the colon arising in a villous adenoma. Hum Pathol 1988; 19: 362-364.

60. McMahon AJ. Squamous carcinoma of the colon: primary or metastatic? Eur J Surg Oncol 1991; 17: 397-402.

61. Wyatt MG, Clarke TJ, Teasdale C. Primary squamous cell carcinoma of the caecum. Eur J Surg Oncol 1991; 17: 392-394.

62. Betancourt C, Berríos G, Peña E. [Squamous cell carcinoma of the colon: a case report.] G EN 1992; 46: 331-335.

63. Vignale R, Espasandin J, Deneo H, Gonzalez V. Halo seborrheic keratosis associated with colon carcinoma. Int J Dermatol 1993; 32: 846-848.

64. Vraux $\mathrm{H}$, Kartheuser $\mathrm{A}$, Haot J et al. Primary squamous-cell carcinoma of the colon: a case report. Acta Chir Belg 1994; 94: 318-320.

65. Alekseev VS, Boľkov VP, Pavlov NV, Karyshev PB. [Squamous cell cancer of the colon with inflammation.] Khirurgiia Mosk 1994; 12: 58.

66. Goodfellow PB, Brown SR, Hosie KB et al. Squamous cell carcinoma of the colon in an asbestos worker. Eur J Surg Oncol 1999; 25: 632-633.

67. Fahim F, Al-Salamah S, Alam MK, Al-Akeely MH. Squamous cell carcinoma of colon and rectum. Saudi Med J 2006; 27: 874-877.

68. Hashimoto $\mathrm{N}$ et al. Primary squamous cell carcinoma of the sigmoid colon. Jpn J Gastroenterol Surg 2013; 46: 302-309.

69. Ito $\mathrm{H}$, Miyakura $\mathrm{Y}$, Tsukui $\mathrm{H}$ et al. Synchronous metastatic squamous cell carcinoma to the colon and cervical lymph nodes from a carcinoma of unknown primary site: a case report. J Surg Case Rep 2016; 2016: rjw084.

70. Ngo N, Edris H, Figueroa JA, Nugent K. Squamous cell carcinoma of the sigmoid colon presenting with severe hypercalcemia. Clin Colorectal Cancer 2014; 13: 251-254.

71. Samo S, Sherid M, Liu K et al. Basaloid squamous cell carcinoma of the sigmoid colon. ACG Case Rep J 2015; 2: 161-164.

72. Ahmad S, Watson N, Shamim K et al. Squamous cell carcinoma of the cecum developing in a patient with long-standing ulcerative colitis and a coexistent carcinoid tumor in the appendix: a case report. Turk J Gastroenterol 2015; 26: $435-437$.

73. Mohamed S. [Primary squamous cell carcinoma of the colon: about a case]. Pan Afr Med J 2017; 27: 124

74. Abdelqader A, Jabaji R, Albugeaey M, Paleseb C. Squamous cell carcinoma of the ascending colon: two cases. J Community Hosp Intern Med Perspect 2017; 7: 53-55. 